\title{
Analysis of Actor Networks in Forest Management as a Buffer for Water Resources in Archipelago Areas (Study on Sei Pulai Protected Forest Area, Riau Islands)
}

\author{
Imam Yudhi Prastya ${ }^{1}$, Maritime University of Raja Ali Haji (UMRAH) \\ Jamhur Poti ${ }^{2}$ Maritime University of Raja Ali Haji (UMRAH) \\ Email: ${ }^{1}$ yudhiimam.umrah.ac.id. ${ }^{2}$ jamhur_poti2000@yahoo.com
}

This study aims to analyze actor networks in the management of Protection Forest as the Pulai River. Pulai River Protected Forest is one of the protected forests on the bintan island of Riau Islands Province in addition to the protected forest of the cat hill, the mountain of galangal and the mountain of the deer. The protected forest of Pulai River is a buffer or provider of water reserves and also as a water catchment area for the Pulai River reservoir. The current level of damage to the protected forest of the river Pulai is very worrying. The damage is caused by illegal logging, conversion of forest areas to residential and community plantations and also the existence of oil palm plantations that enter protected forest areas. In this study qualitative descriptive approach with explanatory level will be used, to see patterns, meaning of actor objects, function, structure, institutionalization, rules of conduct, power relations and actor strategies, placing in-depth interviews as data collection cores. The author concludes that the network of actors in management in Forest Management as a Buffer for Water Resources in the Islands Region has not been formed. This is due to the lack of understanding and agreement that the forest issue is not only a matter of forest rehabilitation. Another thing is about the certainty of ownership rights over land which then has an impact on the fulfillment of the rights regarding the basic needs of the citizens who have been fulfilled. With the issuance of regulations relating to the settlement of land in forest areas, it is at least a new hope to address the core of the problem.

Keywords: Actor Network, Forest Management, archipelago.

\section{Introduction}

This study aims to analyze the network of actors in the management of the Sungai Pulai Protection Forest. Sungai Pulai Protected Forest is one of the protected forests on the Bintan island. The protected forest of Sungai Pulai is a buffer or provider of water reserves and also as a water catchment area for the Sungai Pulai reservoir. For Tanjungpinang citizen, the Sungai Pulai reservoir is the main source of raw water supply for clean water needs which is then operated by the Regional Water Supply Company Tirta Kepri.

The forest should be a catchment area which then becomes a buffer for water sources. Under the Forestry Law number 41 of 1999, protected forests are forest areas that have a primary function as protection of life support systems to regulate water management, prevent flooding, control erosion, prevent sea water intrusion, and maintain soil fertility. Conversion of land functions such as illegal logging, the emergence of settlements and also the emergence of agricultural fields are factors that cause the forest to lose its function.

In forest management, it is suspected that there are more than one agency or institution, both central and regional government. Where these institutions have functions and roles in maintaining and restoring forest functions. At the regional level, forestry authority has shifted from the district or city government to the provincial government. Stakeholders who have the authority and interests related to the protected forest of the Pulai river include; First, in Riau Island Province, forestry authority is under the environment and forestry services. In relation 
to planning and policies in the agency, in terms of technical implementation or policy elaboration, there is a Forest Management Unit. Secondly, the regional water company Tirta Kepri is the party that utilizes the water from the Pulai River reservoir to be produced into clean water. Regional water companies have an interest in maintaining water quality and water discharge in the Pulai River reservoir. In processing and producing water, the PDAM is in the protected forest area of the Pulai River. Third, the Central Government (Ministry of Forestry) through the Watershed Management Center has a role and function in terms of preserving forests as part of the watershed. Fourth, the Tanjungpinang City Government has a slice of authority in terms of territory and population administration. Fifth, the Tirta Madu Palm Oil Plantation which is part of the plantation area located in a protected forest area. Sixth, local people who live and utilize some of the protected forest areas. In addition to the parties mentioned above, there is also a watershed forum that has a concern on forest sustainability as part of the Sungai Pulai watershed.

Riau archipelago province which is an administrative area that is divided into several islands. In total, the territorial sea owned by the Riau Islands Province covers 417,012.97 Kilometers, while the land area of 10,595.41 Kilometers. So the land area of Riau Island Province is only about $4 \%$ and the rest is the ocean.

Based on data from the Statistics Agency, the level of population density in Riau Islands Province in 2015 was 186 people / km2. The highest population density is in Tanjungpinang City at 844 people / km2 and Batam City is at 757 people / km2, and the lowest is in Natuna Regency with a population density of 26 people per kilometer. It is seen that the increase in population density of Batam and Tanjungpinang cities has increased very rapidly in the period of 2011-2015.

Based on hydrology, the bintan island region in general, or Tanjungpinang in particular, does not have sufficient groundwater content. Only in certain areas and the area is very insignificant compared to the area of Bintan Island. In meeting the need for water, it is more likely to rely on surface water (dams, reservoirs etc.), so to ensure the availability of surface water, the existence of forests in this case the Sungai Pulai protected forest that functions in regulating water management (water catchment) is very important.

As explained above Tanjungpinang is city with the narrowest area on one side and with the highest population density compared to other city districts in Riau Islands Province. In addition, if viewed hydrographically, the bintan island region in general, or Tanjungpinang in particular, does not have groundl water content. Only in certain regions and the area is very insignificant compared to the size of the Bintan Island. So with these conditions, to meet the need for clean water can not rely on ground water, but rely on surface water in the form of rivers or reservoirs.

The preservation of protected forests of Sungai Pulai is obliged to be continuously pursued in view of the reservoir water sources other than rainwater also coming from the water from the protected forest. The Sungai Pulai reservoir has a production capacity of 170 liters / second. This capacity is very volatile because in particular the sei pulai reservoir is not sourced from river flow, so the water discharge is affected by the intensity of the rain that occurs. Based on the explanation above, the formulation of the problem is how the network of actors in Forest Management as a Buffer of Water Resources in the Islands Region. 


\section{Methodology}

The method used in this study is qualitative. Qualitative research methods as expressed by Bogdan and Taylor in meleong (2011:4) as a research procedure that produces descriptive data in the form of written or verbal words from people and observed behavior. The research location in this study is Tanjungpinang City, with individual research subjects, actors, institutions identified as actors in the management of the Sungai Pulai Forest.

In this study, to obtain data that is needed several things that concern the author, namely; Primary data is obtained through interviews - depth interviews - and observations which are then poured into fields notes, for secondary data obtained through records and or documents at the relevant institutions or agencies in this study, then media publications and research documents related to the research.

The selection of informants in this study was determined randomly, which was then obtained by informants with the following criteria: a) The informant was part of the network of actors in the management of the Sungai Pulai forest. b) The informant must have knowledge and understanding related to the research topic even though the person concerned is not part of the network of forest management actors. b) occupy a strategic position in the management of water resources, c) have sufficient time, and easily provide information.

In analyzing data, data collection and data analysis do not become an integral part and process simultaneously, and form an interactive cycle. This model also recommends that researchers conduct data collection activities, both during the data collection process, and when the data collection process is complete, still considering the three components of analysis, namely data reduction, data presentation and conclusion in Huberman and Miles (1992: 429)

\section{Discussion}

The locus of this research is the protected forest area of the Pulai river which administratively is located in the Tanjungpinang region, precisely in kampung Tirtomulyo Village, Pinang Kencana Village. Based on the results of the study it was found that there had been a massive conversion of land from the protected forest of the Pulai River. The conversion of the forest function that was designated as a catchment area turned into a community plantation, a residential settlement that was built permanently, a place of worship in the form of mosque and prayer rooms and public cemeteries. The population that inhabits the area (kampong Tirto mulyo) is currently 180 families. The existence of settlements in the area has actually been known and recognized by the government, this can be seen from the presence of the government in the community environment in the form of neighbourhood (Rukun Tangga) 02 from community group (Rukun warga) 02 Kelurahan (Urban Village) Pinang kencana.

Although administratively it is acknowledged but the community has not received public services in the form of paving roads and electricity as in other places. So, in the provision and construction of roads in the village it is carried out independently without assistance from the government. In connection with the electricity network, in 2015 electric poles were installed to the residential areas by PLN (state electricity company), but that year also installed poles were dismantled by PLN on the grounds that the kampung Tirto Mulyo was included in protected forest areas.

Regarding of population administration, the community cannot access in connection with population administration in the form of family cards. Based on Law No. 23 Th 2006 which regulates Population Administration referred to as Family Card is a Family Identity Card 
which contains data about the composition, relationship and number of family members. Family cards (kartu keluarga) must be owned by every family. This card contains complete data about the identity of the Family Head and family members. As we all know that family cards are a basic requirement to get other citizen administration.

Based on information collected from the neighbourhood head 02 of the kampung Tirto Mulyo, starting from 2015, the villagers of Tirto Mulyo could no longer get services related to family card (kartu Keluarga) issuance. On the other hand, an Family Card (kartu Keluarga) is a basic requirement for processing a Identity Card, birth certificate, registering a school and so forth. With such conditions, the citizens take the initiative to be able to get a family card by making information, but they are domiciled in kampung Sidomulyo.

Government regulation number 6 of 2007 concerning Forest Management and Formulation of Forest Management Plans, and Forest Utilization in Article 23 paragraph 1 states that the use of protected forests can only be carried out through activities; utilization of the area, utilization of environmental services and collection of non-timber forest products. Furthermore, in article 24 paragraph 2, it is stated that the use of protected forest kasawan forest is carried out with provisions;

a. Does not reduce, change or eliminate its main function.

b. Limited land for processing.

c. Does not have a negative impact on biophysical and socio-economic.

d. Do not use mechanical equipment and heavy equipment.

e. Do not build facilities and infrastructure that change the landscape.

Determination of the Sunga Pulai Forest as a protected forest through the Decree of the appointment of the Minister of Agriculture No.71 / Kpts / UM / 1978 dated December 1, 1979 and Decree on the stipulation of the Minister of Forestry No. 424 / Kpts -II / 1987 December 28, 1987, the Sunga Pulai Protection Forest has an area of 751.80 hectares. The protected forest of Sungai Pulai is government administration located in Bintan Regency and Tanjungpinang City. The protected forest area of the Pulai River is the area of Tanjungpinang covering an area of approximately 313 hectares in the East Tanjungpinang District, while the remaining 438.80 hectares are administratively located in Bintan Regency. The decree is conceptually referred to as a public policy. The policy contains three connotations, namely government, society and the public. According to Syafarudin (2008: 78) public policy is a government policy with its authority to force people to obey it. So with the issuance of the ministerial decree, the government has the right to control all activities that can change the function of protected forests.

Not all policies run as planned by policy makers. Although the policy has been established, there is no guarantee that the policy can solve the problem because it will depend on how the policy is implemented. According to Winarno (2007: 144), implementation is widely seen as meaning the implementation of laws where various actors, organizations, procedures and techniques work together to carry out policies in an effort to achieve policy objectives. According to Nugroho (2003: 158) suggests that the implementation of policies in principle is a way for a policy to achieve its objectives. So the policy implementation stage plays an important role in a policy in achieving its objectives.

Conceptually there are several things that affect the implementation of a policy. According to Van Metter and Van Horn in Subarsono (2008: 90) stated that: 
a. Policy measures and objectives.

b. Resource.

c. Characteristics of implementing agents.

d. The attitude / disposition of the implementers.

e. Communication between implementing organizations and activities.

f. Economic, social and political environment.

Aspects of communication between organizations and implementing activities and the economic, social and political environment are aspects that influence the success or failure of a policy. These aspects will be part of the discussion in this paper.

Management of forest areas is a very complex activity and involves many parties, both local government and central government. In line with the development of the paradigm in governance and the increasingly complex problems, the management will not be able to be done by one party. In addition, through the development of the concept of government to governance and democracy emphasizes that the state or government is not a single actor in organizing government but it is also important to consider and involve the community and the private sector. According to Peter and Pierre in Pratikno (2008: 19) power relations between countries, markets and society become relatively autonomous and horizontal. Then the implication is that the processes of interest (not regulation) are central to the formulation, retrieval and implementation of public policies.

The need for collaboration or networking between actors in the implementation of government or policy functions is not new. The concept of networks in public policy studies first appeared in the mid-1970s and early 1980s. Scharpf in Gedeona, H. T. (2013: 360) argues "The policy process of both policy formulation and implementation is the result of the inevitable interaction between the plurality of actors with different interests, goals and strategies in an inter-organizational network where certain public affairs or problems are intervened". as explained, it becomes a common practice and in certain conditions it is imperative to establish multi-actor networks in public policy starting from formulation to policy implementation in order to intervene or resolve a public problem.

In relation to the management of the River forest area, it is an activity that touches many aspects and certainly involves many actors in it. Based on the problems that can be traced, there are problems of land ownership that are used for settlements, plantations and public facilities caused by clash of regulations related to the determination of the area into protected forest. These conditions then have 2 main impacts; first, the occurrence of damage to the forest area so that the function of the forest is reduced as a buffer for water sources. Secondly, the people occupying the area are denied their rights to fulfill basic needs (electricity, water, roads and demographic administration).

In responding to and resolving such complex problems, cooperation between institutions is absolutely necessary. If using a policy network perspective as quoted by Suwitri, S. (2008) explains that Policy networks or policy networks are described in several categories. First, it is described as actors, Second, linkages between actors, third, boundary. Furthermore, to help at the empirical level the dimensions of network actors can use several dimensions. According to Waarden, F. V. A. N. (1992);

"Different dimensions of policy networks are more or less explicitly present in the literature, especially that of the sociometric approach, which has gone much further than political science in developing analytical concepts and criteria for 
measurement. Major dimensions of policy networks are: (1) actors, (2) function, (3) structure, (4) institutionalization, (5) rules of conduct, (6) power relations and (7) actor strategies.

With the existence of residents' settlements within protected forest areas, their nature is prohibited because they have a negative impact on the biophysics and will change the condition of the landscape from the forest area. So it is seen from the legal aspect that it is reasonable when the people who inhabit the protected forest area do not get public services as they should as citizens who have the right to get public services from the government.

From the results of interviews conducted with several informants, the fact was that before the area was designated as a protected forest, a part of the area, especially in the kampung Tirtomulyo, had issued a grand letter as proof of land ownership long before the Ministerial Decree was issued. On the basis of the letter it became the basis for the community to dare to open a settlement area, even though it was not based on a certificate of land ownership but at present the ownership of the land was based on a written letter and the best compensation as a derivative of the grand letter. It is this regulatory imbalance that has until today become the core of the problem.

Research conducted there are 3 aspects in the problem of managing protected forest areas of the Pulai River, namely land ownership status, population administration and forest protection and rehabilitation. In addition, there were also found several actors involved in management;

Table 3.1

Forest area management issues and actors

\begin{tabular}{|c|c|}
\hline Aspects & Actors \\
\hline Land Ownership Status & $\begin{array}{ll}\text { - } & \text { Environmental and Forestry Service } \\
\text { - } & \text { Regional Office of the National Land } \\
& \text { Agency } \\
\text { - } & \text { City Land Office } \\
\text { - } & \text { Forest Management Unit } \\
\text { - } & \text { Districts } \\
\text { - } & \text { Kelurahan (urban village) }\end{array}$ \\
\hline Population Administration & $\begin{array}{l}\text { - Districts } \\
\text { - Kelurahan (urban village) } \\
\text { - Department of Population and Civil } \\
\text { Registration } \\
\text { - Regional Financial and Asset Management } \\
\text { Agency }\end{array}$ \\
\hline $\begin{array}{l}\text { Forest Protection and } \\
\text { Rehabilitation }\end{array}$ & $\begin{array}{l}\text { - Watershed Management Center } \\
\text { - Forest Management Unit }\end{array}$ \\
\hline
\end{tabular}

\section{Land Ownership Status}

In the case of overlapping land status, in the era of Joko Widodo's administration on paper it was easy to be resolved through the Presidential Regulation of the Republic of Indonesia Number 88 of 2017 concerning Settlement of Land Acquisition in Forest Areas. The case that occurred in the village of Tirto Mulyo could be resolved if the team went well. Viewed from 
the institutional perspective, the team is not permanent, meaning that the team was formed and worked when land tenure issues occurred. The land that they have occupied and used as fields has the opportunity to get a certificate of ownership if it is supported by relevant facts and data. By using the dimensions mentioned by Waarden, it can be seen that there are actors involved. As stated in article 19 paragraph 2, there is a stated membership composition of the Inver team Control of Land in Forest Areas (tim Inver PTKH) is;

- The Head of the Provincial Office that organizes affairs in the forestry sector.

- Head of the National Land Agency Regional Office.

- Head of Provincial and Regency / City Service that organizes affairs in spatial planning.

- Head of the Provincial Agency that organizes affairs in the field of the Environment.

- Head of the Forest Area Stabilization Center.

- Head of Office in charge of social forestry affairs.

- Head of the local Forest Management Unit.

- Head of Regency / City Land Office.

- Local sub-district head or sub-district official.

- Lurah / local village head.

Actors, types of membership, institutions, rules of the game are listed in the presidential regulation through the division of chapters that contain;

- Pattern of settlement of control and utilization of land in forest areas.

- The team accelerates the settlement of land ownership in forest areas.

- Procedure for resolving land tenure in forest areas.

- Integration of changes in state forest boundaries in regional spatial plans.

- Financing.

\section{Demographic Administration}

There is a lack of clarity about the government, especially Tanjungpinang City in putting people in the kampung Tirtomulyo. In terms of government administration, kampung Tirtomulyo is legal and is recognized by the city government because it has a neighbourhood (Rukun Tangga) 02 from community group (Rukun warga) 02 Kelurahan (Urban Village) Pinang kencana. However, in terms of population administration, the community is experiencing problems, especially starting in 2015, it is no longer possible to take care of the Family cards (kartu keluarga) on the grounds that the area is included in the protected forest. Besides that, every year the community gets the Land Tax and Property Tax Returns. It is indirectly stated that their land status is recognized as ownership status because it enters into a taxable object.

Law number 12 of 1985 concerning land and building tax explains that tax objects that are not subject to the United Nations include protected forests, nature reserves, tourism forests, national parks, grazing lands controlled by villages and state land that has not been encumbered by a right. So if the Tanjungpinang city government refers to the law, the land inhabited by the 
kampung Tirtomulyo is not entitled to determine as a tax object which then has an obligation to pay land and building taxes.

As far as the information obtained in the study, there is currently no initiative from the city government to solve this. If you look at the problem, the actors that need to be involved are Kelurahan (Urban village), Kecamatan (sub district), Regional Asset and Asset Management Agency. So that the people do not become victims of the government's ambiguity in positioning the people of the village of Tirtomulyo. Until the research was conducted there was no policy network in completing the issue.

\section{Forest Protection and Rehabilitation}

In the aspect of forest protection and rehabilitation there are two dominant actors, namely Watershed Management Center, hereinafter referred to as BPDAS and Forest Management Unit, hereinafter referred to as KPH. Pursuant to Article 2 of the Regulation of the Minister of Environment and Forestry of the Republic of Indonesia Number: P.10 / Menlhk / Setjen / OTL.0 / 1/2016 dated 29 January 2016 concerning Organization and Work Procedure of Watershed Management and Protected Forests, mentioning that the Management Office Watersheds and Protected Forests have the task of carrying out the formulation of plans, implementation of forest and land rehabilitation and soil and water conservation, institutional development, control of inland water damage, and evaluation of watershed management and protection forests based on the provisions of legislation. Whereas according to Government Regulation Number 6 of 2007 concerning Forest Management and Formulation of Forest Management Plans and Forest Utilization, one $\mathrm{KPH}$ is to protect forests and nature conservation.

The level of damage to the protected forest area of the Sungai Pulai is so critical, so that BPDAS determines it to be a critical forest. BPDAS has the task of rehabilitating forest areas that are part of the watershed. In its implementation BPDAS in 2015 has carried out forest rehabilitation through planting 200 trees. In the implementation of tree planting it involves the local community. The results of observations and interviews with several informants found that the rehabilitation of the forest did not achieve the desired results because many dry trees burned, not growing because they were not suitable for filamentous soil conditions and might be revoked due to the activities of the local community.

Based on the Law on the latest regional government, it is stated that the affairs or authority of the forestry issue shifts from the authority of the district or city to the authority of the provincial government through the Forestry Service and the environment. With regard to forest management, the provincial government through the environmental and forestry services and the Regional Technical Implementing Unit of the Forest Management Unit as technical implementers. In terms of authority, the agency has the authority to make forest management plans while the technical implementers, including supervision and prosecution are the tasks of the Regional Technical Implementation Unit of the Forest Management Unit. Based on observations and the results of interviews that have been conducted, it is found that the Regional Technical Implementation Unit of the Forest Management Unit has not been effective in implementing its authority. Ineffectiveness is caused by internal factors and external factors. Internal factors; resources owned by both human resources, budget and supporting facilities. External Factors; social conditions and legal uncertainty. 
Using the dimensions mentioned by Waarden, it can be concluded that the actor network is in terms of Forest Protection and Rehabilitation. Actors involved in dealing with forest area management policies are still partial, not connected to one another in terms of subdimensions of linkages, institutions and rules of the game.

\section{Conclusion}

The results of this interim discussion the authors conclude that the network of actors in Forest Management as a Buffer for Water Resources in the Islands Region is not optimal. Each actor is still carrying out their respective functions without seeing the issue of protected forest areas as a complex issue, not only regarding the problem of forest destruction but also needs to be seen from the social community.

issue of Land Election Status with the issuance of Presidential Regulation of the Republic of Indonesia Number 88 of 2017 concerning Settlement of Land Acquisition in Forest Areas can be a guide in the formation and implementation of actor networks. However, because the regulation is relatively new so it has not been effective. Whereas from the aspect of population administration and protection and rehabilitation of forest the actor network has not been formed at all.

\section{References}

Abidin, Said Zainal. 2002. Kebijakan Publik. Jakarta : Yayasan Pancur Siwah.

Bungin, Burhan. (ed). (2008). Metodologi Penelitian Kualitatif : Aktualisasi Metodologis ke Arah Ragam Varian Kontemporer, PT Raja Grafindo Persada. Jakarta.

Gedeona, H. T. (2013). Tinjauan Teoritis Pengelolaan Jaringan ( Networking Management )

Dalam Studi Kebijakan Publik. Jurnal Ilmu Administrasi, X(3).

Handayaningrat, Soewarno. 1992. Pengantar Studi Ilmu Administrasi dan Manajemen. Jakarta : Cv Haji Masagung.

Maleong L.J. 2011 Metode Penelitian Kualitatif Edisi Revisi. Bandung : PT Remaja Rosdakarya

Miles, Matthew dan Huberman, A. Michael. 1992. Analisis Data Kualitatif: Buku Sumber Tantang Metode-Metode Baru. Jakarta:UI Press.

Nugroho, Riant D. 2003. Kebijakan Publik Formulasi Implementasi dan Evaluasi. Jakarta : PT.Elex Media Komputindo

Pratikno. (2008). Manajemen Jaringan dlm Perspektif Strukturisasi.pdf. Jurnal Kebijakan Dan Administrasi Publik, 12(1).

Subarsono. 2008. Analisis Kebijakan Publik. Yogyakarta: Pustaka Pelajar.

Suwitri, S. (2008). Jejaring Kebijakan Dalam Perumusan Kebijakan Publik. Jurnal Delegasi, Jurnal Ilmu Administrasi, STIA Banjarmasin, Terakreditasi KepDirjenDikti No. 56/DIKTI/Kep/2005, VI(3)

Syafarudin. 2008. Efectivitas Kebijakan Pendidikan. Jakarta: PT. Rineka Cipta

Waarden, F. V. A. N. (1992). Dimensions and types of policy networks. European Journal of Political Research, 21(2)

Winarno, Budi. 2007. Kebijakan Publik, Teori dan Proses. Jakarta: PT. Buku Kita. Kepulauan Riau Dalam Angka 2015,Badan Pusat Statistik Provinsi Kepulauan Riau. 